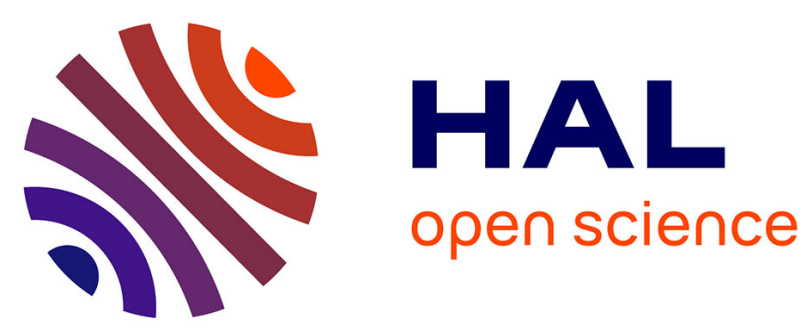

\title{
Assessment of the acrylamide intake of the Belgian population and the effect of mitigation strategies
}

Wendie Liliane Claeys, Katleen Baert, Frédéric Mestdagh, Jan Vercammen, Paul Daenens, Bruno de Meulenaer, Guy Maghuin-Rogister, André Huyghebaert

\section{To cite this version:}

Wendie Liliane Claeys, Katleen Baert, Frédéric Mestdagh, Jan Vercammen, Paul Daenens, et al.. Assessment of the acrylamide intake of the Belgian population and the effect of mitigation strategies. Food Additives and Contaminants, 2010, 27 (09), pp.1199-1207. 10.1080/19440049.2010.489577. hal-00604049

\section{HAL Id: hal-00604049 https://hal.science/hal-00604049}

Submitted on 28 Jun 2011

HAL is a multi-disciplinary open access archive for the deposit and dissemination of scientific research documents, whether they are published or not. The documents may come from teaching and research institutions in France or abroad, or from public or private research centers.
L'archive ouverte pluridisciplinaire HAL, est destinée au dépôt et à la diffusion de documents scientifiques de niveau recherche, publiés ou non, émanant des établissements d'enseignement et de recherche français ou étrangers, des laboratoires publics ou privés. 


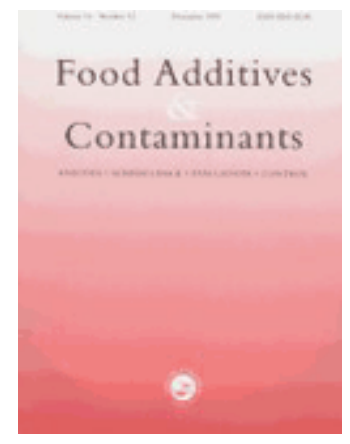

\section{Assessment of the acrylamide intake of the Belgian population and the effect of mitigation strategies}

\begin{tabular}{|r|l|}
\hline Journal: & Food Additives and Contaminants \\
\hline Manuscript ID: & TFAC-2010-046.R1 \\
\hline Manuscript Type: & Original Research Paper \\
\hline Author: & 19-Apr-2010 \\
\hline Complete List of Authors: & $\begin{array}{l}\text { Claeys, Wendie; FASFC, Policy Control } \\
\text { Baert, Katleen; FASFC, Policy Control } \\
\text { Mestdagh, Frédéric; Ghent University, Department of Food Safety } \\
\text { and Food Quality } \\
\text { Vercammen, Jan; FASFC, Laboratories } \\
\text { Daenens, Paul; Catholic University Leuven } \\
\text { De Meulenaer, Bruno; Ghent University, Department of Food Safety } \\
\text { and Food Quality } \\
\text { maghuin-rogister, guy; University of Liège, CART } \\
\text { Huyghebaert, André; Ghent University, Department of Food } \\
\text { Technology and Nutrition }\end{array}$ \\
\hline Methods/Techniques: & $\begin{array}{l}\text { Risk assessment, Exposure assessment, Probabalistic modelling, } \\
\text { Chromatography - LC/MS }\end{array}$ \\
\hline Additives/Contaminants: & Process contaminants - acrylamide \\
\hline Food Types: & Processed foods \\
\hline &
\end{tabular}

\section{SCHOLARONE Manuscripts}




\section{ASSESSMENT OF THE ACRYLAMIDE INTAKE OF THE BELGIAN POPULATION} 2 AND THE EFFECT OF MITIGATION STRATEGIES

3

4 Wendie Claeys ${ }^{1, *}$, Katleen Baert ${ }^{1}$, Frédéric Mestdagh ${ }^{2}$, Jan Vercammen ${ }^{3}$, Paul Daenens ${ }^{4}$,

5 Bruno De Meulenaer ${ }^{2}$, Guy Maghuin-Rogister ${ }^{5}$, and André Huyghebaert ${ }^{2}$

6

$7 \quad{ }^{1}$ DG Control Policy, Federal Agency for the Safety of the Food Chain, Belgium

$8{ }^{2}$ nutriFOODchem unit, Department of Food Safety and Food Quality, Faculty of Bioscience

9 Engineering, Ghent University, Belgium

$10{ }^{3}$ Laboratory of Gentbrugge, DG Laboratories, Federal Agency for the Safety of the Food Chain, 11 Belgium

$12{ }^{4}$ Faculty of Pharmaceutical Sciences, Catholic University Leuven, Belgium

$13{ }^{5}$ Centre d'analyse des résidus en Traces (CART), Faculty of Veterinary Medicine, University of 14 Liège, Belgium

15

16 *Author to whom correspondence should be addressed:

17 DG Control Policy, Federal Agency for the Safety of the Food Chain,

18 Boulevard du Jardin botanique 55, B-1000 Brussels, Belgium

19 Tel: +32-(0)2-211.87.02; Fax: +32-(0)2-211.87.22

20 E-mail : wendie.claeys@favv.be 


\section{Abstract}

23 The acrylamide (AA) intake of the Belgian consumer was calculated based on AA monitoring 24 data of the Belgian Federal Agency for the Safety of the Food Chain (FASFC) and consumption 25 data of the Belgian food consumption survey coordinated by the Scientific Institute for Public 26 Health (3214 participants of 15 years or older). The average AA exposure, calculated 27 probabilistically, was $0.4 \mu \mathrm{g} / \mathrm{kg}$ bw/day (P97.5 = $1.6 \mu \mathrm{g} / \mathrm{kg}$ bw/day) with as main contributors to 28 the average intake chips (23\%), coffee (19\%), biscuits (13\%) and bread (12\%). Additionally, the 29 impact of a number of AA mitigation scenarios were evaluated (German minimisation concept, 30 scenarios for mitigation from the literature, signal values), which is an important issue for public 31 health as well as for policymakers. Specific actions in cooperation with the food industry to 32 reduce the $A A$ content of foods seems to be a more efficient strategy than mere implementation 33 of signal values. Considering that an important share of the AA intake is due to prepared meals, 34 the catering industry as well as the consumer need to be better informed on the various 35 possibilities for keeping the AA content of meals as low as possible. 36

37 Keywords: acrylamide; risk assessment; exposure; food; mitigation; probabilistic 38 


\section{Introduction}

Acrylamide (AA, $\mathrm{CH}_{2}=\mathrm{CHCONH}_{2}$, CAS No. 79-0601, EC No. 201-173-7) is neurotoxic, and probably genotoxic and carcinogenic to humans as well. Recently, the European Chemicals Agency (ECHA) announced to include AA on the European Union's candidate list of Substances of Very High Concern (ECHA 2009). Under the ECHA proposal, AA has been listed as a category 2 carcinogen and a category 2 mutagen. The chemical has a large number of industrial applications including the production of polyacrylamides, which are among others used in cosmetics, pesticides, paints, as a flocculant in water treatment and in the paper industry. AA is also present in cigarette smoke (JECFA 2005; IARC 1994).

In 2002 it was demonstrated that relatively high levels of AA are formed during heating of certain foods (baking, roasting, frying). Since then, intensive research has been conducted regarding the various formation mechanisms and the toxicology of AA (e.g. bio-availability), the development of accurate analytical methods (e.g. cheap and fast screening methods), factors that influence the AA content of foods (e.g. storage), etc. (Tardiff et al. 2010; EFSA 2008a; Friedman and Levin 2008; Claeys et al. 2005; Stadler and Scholz 2004; Taeymans et al. 2004).

The observed AA levels in food are a result of competitive, complex processes of formation and elimination or degradation (Mottram et al. 2002). The largest amount of AA is accumulated during the last stages of baking, roasting or frying when the moisture content of the food drops and the surface temperature rises, except for coffee where the AA level drops significantly during the later stages of the roasting process. AA appears to be stable in the large majority of foodstuffs. Grounded coffee, where the AA content decreases during storage, is once more an exception (Lanz et al. 2006; Hoenicke and Gatermann 2005).

Until present, there are no legal regulations regarding the AA content of food, at a national nor at a European level. Germany is the only country with a systematic mitigation strategy (BVL, 2005) and the only legal action undertaken so far, was the withdrawal of child biscuits containing $>1000 \mu \mathrm{g} \mathrm{AA} / \mathrm{kg}$ from the Swiss market in 2005 (Grob 2007). In California, a court agreement was reached with a number of important chips and crisp producers and some fast food chains to reduce the $A A$ content of their products significantly and to put warning labels regarding the presence of AA on the package (Hill 2008). 
The Belgian Federal Agency for the Safety of the Food Chain (FASFC) monitors already for a number of years the AA content of different foodstuffs. When AA is detected at a level above $1000 \mu \mathrm{g} / \mathrm{kg}$, the producer is urged to take possible mitigation actions. The vast amount of data acquired through the monitoring programme as well as the availability of a nationwide Belgian food consumption survey allows the assessment of the dietary exposure of the Belgian population to AA. The present study is the first large-scale study conducted with respect to the $A A$ intake of the Belgian consumer.

\section{Materials and Methods}

\section{Food consumption data}

Food consumption data were obtained from the Belgian Food Consumption Survey (BFCS) in 2004 performed by the Scientific Institute of Public Health (Devriese et al. 2005). The survey involved 3214 participants of 15 years or older, which were interviewed twice about their consumption during the last 24 hours (repeated non-consecutive $24 \mathrm{~h}$ recall) in combination with a self-administered food frequency questionnaire. The fieldwork was spread over one year to anticipate seasonal effects and was carried out by trained dieticians. The selection of interviewed people and the moment of the interview were chosen in order to obtain a representative consumption profile of the Belgian population over 1 year anticipating seasonal effects.

In this study, the total data sets, including zero intakes ('zero consumption days'), was used as part of an 'average' diet. It is remarked that the duration of the consumption survey affects the distribution of consumption data, particularly the upper percentiles or the group of high or frequent consumers. As such, a brief survey often underestimates the consumption of less frequently consumed foods, but at the same time overestimates the quantities of frequently consumed foods. High percentiles based on a one to two days consumption survey are often an overestimation compared to high percentiles obtained on the basis of a seven-day survey. The reliability of the high percentiles depends not only on the duration of the survey, but also on the number of people or data on which their calculation is based. Percentiles that are calculated 
based on a limited amount of data, have a higher uncertainty and give only a rough indication of the higher consumption levels. According to Kroes et al. (2002), a high percentile P (> P75) can only be evaluated with sufficient accuracy when the sample size $n$ satisfies with $n(1-P) \geq 8$. The minimum amount of data thus required for P95, P97.5 and P99 can be estimated as 160, 320 and 800 respectively. The same restrictions apply to the lower percentiles (EFSA 2008b).

\section{Acrylamide concentration data}

AA levels were measured in various foodstuffs on the Belgian market within the framework of the monitoring programme of the FASFC. The AA content of the samples was determined by a LC-MS accredited method in the FASFC laboratory of Gentbrugge, with a limit of quantification (LOQ) of $50 \mu \mathrm{g} / \mathrm{kg}$ and a limit of detection (LOD) of $25 \mu \mathrm{g} / \mathrm{kg}$. After AA extraction, defatting and further clean-up of the sample over an Oasis HLB SPE column, $10 \mu \mathrm{l}$ was injected on an Sequant ZIC-HILIC column $(2.1 \mathrm{~mm} \times 150 \mathrm{~mm} 5 \mu \mathrm{m}$, equipped with a pre-column $)$ with acetonitrile as mobile phase, coupled to a triple quadrupole mass spectrometer operating in APCI mode (atmospheric pressure chemical ionization) (TSQ Quantum Ultra, Thermo Fisher Scientific, USA). The content was measured in $\mathrm{MS}^{2}$ on the ions $\mathrm{m} / \mathrm{z} 72$ and $52(\mathrm{AA})$ and 75 and 58 (labelled AA, used as internal standard). Depending on the matrix, the recovery is situated between 81 and $100 \%$. The extended measurement uncertainty is situated between $26 \%$ (clean matrix) and $52 \%$ (dirty matrix).

Statistical comparison of the AA levels measured between 2002 and 2007 showed no decrease or increase of the AA level as a function of time. Consequently, data from 2002 until 2007 could be pooled for calculating the intake, which resulted in a data set of 759 data. The statistical analysis of the data was performed with SPSS ${ }^{\circledR} 11.0$ for Windows (SPSS Inc., USA). The Kolmogorov-Smirnov test was used to test normality. Means were compared using analysis of variance (one-way ANOVA) and Post Hoc Multiple Comparison tests (Tukey when variances were equal or Games-Howell when variances were unequal). Homogeneity of variances was tested using the Levene test.

For the exposure assessment, foods were grouped in twelve categories: chips, crisps, coffee (liquid), coffee surrogate (liquid), bread, bread rolls (including pastry), toast, biscuits, 
125 gingerbread, almond or sweet spiced biscuits, chocolate, popcorn, breakfast cereals and cereal 126 bars. The classification is based on the AA levels in different foodstuffs and is in line with the 127 grouping applied in other studies (Mestdagh et al. 2007; Boon et al. 2005; Matthys et al. 2005).

128 The AA data were further expanded with German data from the AA European Monitoring 129 Database, which is compiled by the Institute for Reference Materials and Measurements (IRMM 130 2006). Based on a statistical analysis showing no significant differences, the Belgian AA 131 database could be supplemented with German data for chips, crisps, chocolate, coffee, biscuits 132 and sweet spiced biscuits. In total, the AA dataset contained more than 3000 results.

133

134 Estimation of the acrylamide intake

135 The AA intake was determined per food group and overall by a probabilistic approach 136 considering all data or the full distribution of the different variables (i.e. AA content and 137 consumption). Hereto, a (1-dimensional) Monte Carlo simulation was performed with 100,000 138 iterations. To evaluate the uncertainty of the sampling, 'bootstrap sampling' (2-dimensional 139 Monte Carlo model) was applied. In this method $n$ observations (AA concentration and 140 consumption of the relevant food) were theoretically resampled from the original dataset 141 resulting in a 'bootstrap' dataset with $n$ observations. By repeating this process 500 times, 500

142 'bootstrap' datasets are obtained, on which the same statistical calculations $\left(\right.$ e.g. $97.5^{\text {th }}, 99.9^{\text {th }}$ 143 percentile, etc.) can be applied as on the original data set. As such a 'bootstrap' distribution of $14450097.5^{\text {th }}, 99.9^{\text {th }}$ percentiles, etc. is created that characterizes the uncertainty of the original 145 data set (Vose 2006). The model input distributions were randomly sampled by the Latin 146 Hypercube method. Calculations were performed by the software @Risk ${ }^{\circledR}$ (Palisade 147 Corporation, Version 4.5.5, NY, USA).

148 AA concentrations below the quantification limit (LOQ) were replaced by LOQ/2 ('middle 149 bound scenario'). For the conversion of the AA level of roasted or grounded coffee beans 150 (coffee surrogate) to liquid coffee (coffee surrogate) a conversion factor of 0.046 was applied 151 (van Dooren et al., 1995). Regarding the AA level of chocolate biscuits, chocolate and biscuit 152 were considered separately. Based on chocolate levels mentioned on the package it was 153 assumed that $40 \%$ of the biscuit consists of chocolate. Variability in preparation conditions (e.g. 
154 deep-frying of chips, toasting of bread, etc.) was not taken into account.

\section{Results and Discussion}

157

158

159

160

161

162

163

164

165

166

167

168

169

170

171

172

173

174

175

176

177

178

179

180

181

\section{Dietary exposure of the Belgian consumer to acrylamide}

Table 1 shows the AA intake per food group and the overall AA intake of the Belgian population. The contribution of the most relevant food groups to the AA intake (contribution > $1 \%)$ is also shown in Figure 1.

The average AA intake was calculated as $0.35 \mu \mathrm{g} / \mathrm{kg}$ bw/day (P50 $=0.2 \mu \mathrm{g} / \mathrm{kg}$ bw $/$ day). For high consumers the intake may be several times higher, amounting to $1.58 \mu \mathrm{g} / \mathrm{kg} \mathrm{bw} / \mathrm{day}$ for the $97.5^{\text {th }}$ percentile or P97.5. Overall, about $6 \%$ of the population has an intake higher or equal to the average intake of $1 \mu \mathrm{g} / \mathrm{kg}$ bw estimated by the Joint FAO/WHO Expert Committee on Food Additives (JECFA 2005).

[Table 1]

On average, chips contributed the most to the AA intake (23\%), followed by coffee $(19 \%)$, biscuits (13\%) and bread (12\%) (Figure 1). For the lower intake percentiles, coffee and bread appeared to be most important sources of AA, whereas for the higher percentiles ( $\geq$ P85) chips, crisps and biscuits became more important sources. This reflects the difference in dietary pattern according to the AA intake (Dybing et al. 2005; Matthys et al. 2005).

The AA level, and as such the contribution to the AA intake, of different food groups and of foods within the same food group can vary greatly depending on the formulation of the food, manufacturing conditions, etc. The contribution of a food or food group to the intake is however, not only defined by its AA level, but also by the amount consumed. For example, gingerbread and coffee surrogate contributed relatively little to the exposure despite their relatively high mean AA level (for Belgium, the mean AA level is $692 \pm 566 \mu \mathrm{g} / \mathrm{kg}$ for gingerbread and $2531 \pm$ $825 \mu \mathrm{g} / \mathrm{kg}$ for coffee surrogate powder). With respect to bread the opposite is observed (mean AA level for bread $=30 \pm 9 \mu \mathrm{g} / \mathrm{kg}$ ) due to its high consumption compared to e.g. gingerbread 
182 and coffee surrogate powder.

183

184 [Figure 1]

185

186

The AA intake given in Table 1, corresponds well to the range of values calculated previously

187 for Belgium (restricted target population of adolescents and visitors of a university canteen)

188 (Mestdagh et al. 2007; Matthys et al. 2005) and reported for other European countries (Boon et

189 al. 2005; Dybing et al. 2005; Svensson et al. 2003). In general, values between 0.3 to $2.0 \mu \mathrm{g}$

$190 \mathrm{AA} / \mathrm{kg} \mathrm{bw/day}$ are reported for the average AA intake of adults. The high intake percentiles (P90

191 to P97.5) range from 0.6 to $3.5 \mu \mathrm{g} / \mathrm{kg} \mathrm{bw} /$ day with $5.1 \mu \mathrm{g} / \mathrm{kg} \mathrm{bw} /$ day reported for P99. Food that

192 contribute most to the AA intake are in general chips (16-30\%), crisps (6-46\%), coffee (13-39\%),

193 fine bakery and sweet biscuits (10-20\%), and bread and rolls/toast (10-30\%). Other relevant

194 foodstuffs contribute less than $10 \%$ to the intake (WHO 2006; JECFA 2005). The absolute

195 figure of the exposure and the relative contribution of each food group to the exposure may

196 differ from study to study, depending on the number and nature of the food groups considered,

197 the methodology applied for the calculation, the type of consumption survey, etc. (Dybing et al.

198 2005; JECFA 2005).

199 Any exposure assessment is confronted with a number of uncertainties (Kroes et al. 2002).

200 In this study, the long-term intake was predicted based on a two-day consumption survey and

201 consumption data were considered to be independent. The linkage between the analyzed and

202 consumed food items, the categorization into food groups, the conversion factors applied (i.e.

203 for chocolate in chocolate biscuits and for liquid coffee), and the fact that variability in

204 preparation conditions was not accounted for and that values below the LOQ were unknown

205 and replaced by LOQ/2, are additional sources of uncertainty in the estimated AA intake.

\section{Risk characterization}

207 Given that AA is probably genotoxic and carcinogenic to humans (IARC group 2A) (JECFA 208 2005; IARC 1994), it is recommended to keep the AA exposure 'as low as reasonably 209 achievable' (ALARA). Nevertheless, to prioritise risks associated with unavoidable contaminants 210 that are both genotoxic and carcinogenic, the 'margin of exposure' (MOE) concept has been put 
211 forward (EFSA 2005). The MOE is the ratio between a particular point on the dose-response 212 curve leading to tumours in experimental animals and the exposure. The size of the MOE gives 213 an indication about the possible extent of the risk. The higher the MOE, the lower the risk of 214 exposure to the component concerned. The Scientific Committee of the European Food Safety 215 Authority (EFSA) considers the figure of 10,000 or higher as (in general) being of low concern 216 from a public health point of view and might reasonably be considered as a low priority for risk 217 management actions. For AA MOE values between 50 and 2000 have been reported, 218 depending on the exposure data and toxicological values used (Table 2). The JECFA calculated 219 a MOE of 300 based on an average exposure of $1 \mu \mathrm{g} \mathrm{AA} / \mathrm{kg}$ bw/day and a BMDL10 (the lower 220 confidence limit on the benchmark dose associated with $10 \%$ response) of $300 \mu \mathrm{gA} / \mathrm{kg}$ 221 bw/day for the induction of breast tumours in rats. For high consumers with an intake of $4 \mu \mathrm{g}$ 222 AA/kg bw/day, the MOE was 75 (JECFA 2005). The average $(0.2 \mu \mathrm{g} / \mathrm{kg} \mathrm{bw} /$ day) and the P97.5 $223(1.6 \mu \mathrm{g} / \mathrm{kg} \mathrm{bw} /$ day $)$ intake calculated in this study, would thus correspond to MOE values of 1500 224 and 188 respectively. Such low MOE values imply that additional efforts have to be taken for 225 reducing the AA content in foods and that $A A$ is a process contaminant of high priority. (For 226 comparison: MOE values between 17,900 and 9500 are given for the polycyclic aromatic 227 hydrocarbons (EFSA 2008c)).

$229 \quad$ [Table 2]

\section{Possible strategies to reduce the acrylamide exposure}

232 Various methods are reported in the literature to reduce the AA content of food, such as the 233 selection of potato, wheat and other plant cultivars with low levels of the AA precursors 234 asparagine and glucose, the removal of the AA precursors (e.g. soaking of potatoes, hydrolysis 235 of asparagine to aspartic acid using asparaginase), adaptation of process and storage 236 conditions (temperature, time, water activity $\left(\mathrm{a}_{\mathrm{w}}\right)$ and $\mathrm{pH}$ ), adding ingredients that inhibit the $\mathrm{AA}$ 237 formation (acids, amino acids, antioxidants, non-reducing sugars, chitosan, garlic components, 238 protein hydrolysates, proteins, multivalent ions), the removal or "capture" of AA through 239 chromatography, evaporation or polymerization (Friedman and Levin 2008; Claeys et al. 2005; 
240 Stadler and Scholz 2004; Taeymans et al. 2004).

241 Table 3 shows the effect of some of the specific AA mitigation possibilities reported in 242 literature on the dietary exposure. It should be noted however, that the reduction percentages 243 mentioned are indicative values and that the yield of the proposed mitigation possibilities might 244 be different in practice (for one because there are different types of biscuits, breads, etc. with 245 their own recipe, process conditions, etc.). Furthermore, the reductions mentioned are often 246 based on laboratory (model) experiments, of which the industrial applicability has in most cases 247 not been evaluated yet.

248 For $50 \%$ of the population, the AA intake is primarily due to the consumption of bread and 249 coffee. The AA content of bread is for $>99 \%$ located in the crust (Surdyk et al. 2004). Some of 250 the AA mitigation options for bread mentioned in literature are amongst others the addition of $251 \mathrm{Ca}^{2+}$ or $\mathrm{Mg}^{2+}$ to the dough (resulting in a potential reduction of $20 \%$ of the $\mathrm{AA}$ content), a 252 prolonged yeast fermentation of the dough (50 to $77-78 \%$ reduction), and addition of a high 253 dose of glycine (80\% reduction) (Claus et al. 2004; Fredriksson et al. 2004). Assuming that a 254 reduction of $60 \%$ of the AA content in bread is possible (scenario 1), the P50 and P75 of the AA 255 intake could be significantly reduced with almost 30\% (Table 3).

256 With respect to coffee, only a few options for reducing the AA level are put forward such as 257 the selection of coffee bean species, darker roasting of the beans, a prolonged shelf life and the 258 use of asparaginase (Lanz et al. 2006; Hoenicke and Gatermann 2005). If the AA level of coffee 259 could be reduced with $30 \%$ (scenario 2), the P50 and P75 of the AA intake would be decreased 260 with 15-16\%.

261 Other major sources of $A A$ in the diet are chips, crisps and biscuits. The AA content in 262 biscuits could be reduced with $70 \%$ by adjusting the baking process and by replacing glucose 263 and fructose with sucrose (Gökmen et al. 2007; Graf et al. 2006) (scenario 3). Application of 264 these measures would reduce the average intake with 9\%. For potato products, a significant 265 reduction of the AA level is reported when potatoes are soaked or blanched in an acetic acid 266 solution (40-80\%) or at $70^{\circ} \mathrm{C}$ for 10 to $15 \min (65-96 \%)$ before frying (Mestdagh et al. 2008a,b; 267 Kita et al. 2004). Reducing the baking temperature from $185^{\circ} \mathrm{C}$ to $175^{\circ} \mathrm{C}$ can reduce the $\mathrm{AA}$ 268 level of potato products with $35 \%$ (scenario 4). Such an adjustment of the baking process 
269 results in a $\sim 10 \%$ reduction of the average $A A$ intake, which is of the same order of magnitude 270 as the average reduction of $13 \%$ determined by Boon et al. (2005) for the Dutch consumer. For 271 a high consumer of fried potato products, the intake can even be reduced with $20 \%$.

272 In addition, Boon et al. (2005) calculated that the AA intake decreases on average with about $2734 \%$ when the AA level in gingerbread is reduced with $60 \%$, which can be obtained when sodium 274 bicarbonate is used instead of ammonium carbonate as baking agent (scenario 5). In this study, 275 a similar reduction of the intake was obtained for the higher percentiles. Boon et al. (2005) 276 determined also the reduction that would be achieved when the two latter mitigation options are 277 combined (scenario 4 and 5 ) and obtained an average reduction of $17 \%$. A comparable 278 reduction of 9 to $25 \%$ for the higher intake percentiles was calculated in this study.

279 Seal et al. (2008) addressed the effect of some mitigation options on the AA intake as well, 280 discussing not only the benefits (reduction of the AA intake) but also the risks (health, quality or 281 nutritional implications). The mitigation scenarios studied by Seal et al. (2008) decreased the 282 exposure by 1 to $14 \%$, which is the same range as observed in this study. Application of all 283 mitigation measures simultaneously resulted in a reduction of $31-39 \%$, depending on the 284 percentile of exposure considered.

A possible policy measure for reducing the AA intake is by establishing signal values (action 289 values). In this respect, Germany introduced in 2002 the 'minimisation concept', which pursuits 290 a gradual reduction of the AA levels in foodstuffs while retaining the product's properties (BVL, 291 2005). In this concept the lowest AA level of $10 \%$ of the food with the highest AA concentration 292 (P90) is taken as a signal value, with a ceiling of $1000 \mu \mathrm{g} \mathrm{AA} / \mathrm{kg}$ food product. The German P90 293 signal value is revised each year and reduced when necessary. A signal value can be 294 maintained, but never increased. When a signal value is exceeded, it is discussed with the 295 companies involved which actions might be taken to lower the AA level.

296 Table 4 shows the effect of the German 2008 signal values on the total AA intake of the 297 Belgian consumer (see bottom line of the table). Hereto, AA levels above the German signal 
298 values were replaced by the P90 signal value. It should be noted that there are no German 299 signal values given for chocolate, bread, bread rolls, popcorn and cereal bars. For biscuits the 300 signal value for diet biscuits was applied. For toast the signal value of knäckebröd was 301 considered, but this value turned out to be higher than the levels measured for toast. The effect 302 of applying the P90 signal value concept on the Belgian data (P90 of Belgian AA concentration 303 data as signal value) is also presented in Table 4, (i) for each food group separately and (ii) for 304 all food groups together. 305

306 [Table 4] 307

308 Application of the German signal values on the Belgian data results in a significant reduction 309 of the intake for the higher ( $\geq$ P95), but not for the lower intake percentiles. This can partly be 310 explained by the fact that the signal values are P90 values limiting the higher AA concentration 311 data. In addition, the intake at these percentiles is mainly determined by bread and coffee; no 312 German signal value is presented for bread and in the case of coffee less than $2 \%$ of the 313 samples exceeds the German signal value. Regarding the hypothetical Belgian signal values, a 314 similar observation is made.

315 As expected, the introduction of P90 signal values affects the intake mainly through the food 316 groups that contribute most to the exposure, namely chips, bread and biscuits.

\section{Conclusion}

319 AA is formed mainly during heating of carbohydrate-rich food. AA has always been present in 320 food and is as such not a new contaminant. The derived MOE values however, indicate that 321 additional efforts to reduce the AA exposure are a prerequisite.

322 In this study, the effect of some mitigation strategies on the AA exposure was examined. The 323 most efficient approach for reducing the AA exposure seems to be the reduction of the AA 324 content in foodstuffs that are potentially important contributors to the AA intake rather than the 325 introduction of signal values (action limits). When starting from food with a high AA level, an 326 already significant reduction of the dietary exposure can be achieved with some relatively minor 
327 measures. Signal values or action limits can be a useful tool for policymakers to encourage the 328 food industry to take action by means of a specific AA value. It is nevertheless the task of the 329 food industry to ensure that the AA content of their products is as low as possible. In literature 330 several possibilities are proposed for reducing the AA level in food. For example, the CIAA 331 (Confederation of the food and drink industries of the EU) developed the "AA Toolbox", which

332 contains a brief description of possible intervention steps evaluated in cooperation with industry 333 for reducing the AA content of food products and has published AA pamphlets for five different 334 sectors (CIAA 2009 a \& b). However, also the consumer has to take responsibility for reducing 335 his AA intake. It is estimated that about half of the AA intake results from home-made meals or 336 meals prepared in restaurants (Grob 2007). Even by means of some simple measures such as 337 avoiding excessive browning when frying, baking or roasting potato and cereal products, the AA 338 intake can be significantly reduced. In addition, the recommendations of having a diversified diet 339 including sufficient vegetables and fruit, without exaggerating the consumption of fried food, are 340 still valid and help to reduce the AA intake (Mestdagh et al. 2007).

341 Finally, it must be stressed that awareness of the food industry and the consumer as well as 342 a clear information campaign, are indispensable for dealing with the AA issue.

\section{Acknowledgements}

345 The authors would like to acknowledge the Belgian Institute of Public Health for access to the 346 consumption data, and the Scientific Committee of the Belgian Federal Agency for the Safety of 347 the Food Chain (FASFC) for their guidance of this study. Frédéric Mestdagh is post-doctoral 348 researcher funded by the Research Foundation Flanders (FWO Vlaanderen).

\section{References}

352 Boon P, de Mul A, van der Voet H, van Donkersgoed G, Brette M, van Klaveren J. 2005. 353 Calculations of dietary exposure to acrylamide. Mut. Res. 580: 143-155.

354 BVL. 2005. Bundesamt für Verbraucherschutz und Lebensmittelsicherheit. 
Minimierungskonzept zur Senkung der Acrylamidgehalte in Lebensmitteln [Internet]. Germany: BVL; [cited 2005 Nov 28]. Available from: http://www.bvl.bund.de/cln_027/nn_592438/DE/01__Lebensmittel/03_UnerwStoffeUndOrga nismen/04_Acrylamid/00_Minimierungskonzept/minimierungskonzept_node.html_nnn=t rue

CIAA. 2009a. Confederation of the food and drink industries of the EU. The CIAA acrylamide "toolbox". February 2009, Rev. 12 [Internet]. EU: CIAA ; [cited 2009 Feb 16]. Available from: http://www.ciaa.be/asp/documents/brochures_form.asp?doc_id=65

CIAA. 2009b. Confederation of the food and drink industries of the EU. Acrylamide Pamphlets[Internet]. EU: CIAA; [cited 2009 Feb 16]. Available from: http://www.ciaa.be/asp/documents/l1.asp?doc_id=822

Claeys W, De Vleeschouwer K, Hendrickx M. 2005. Quantifying the formation of carcinogens during food processing: acrylamide. Trends Food Sci. Technol. 16: 181-193.

Claus A, Carle R, Schieber A. 2008. Acrylamide in cereal products: A review. J. Cereal Sci. 47: $118-133$.

Devriese S, De Backer G, De Henauw S, Huybrechts I, Kornitzer K, Leveque A, Moreau M, Van Oyen H. 2005. The Belgian food consumption survey: aims, design and methods. Arch. Public Health 63: 1-16.

Dybing E, Farmer P, Andersen M, Fennell T, Lalljle S, Muller DJ, Olin S, Peterson B, Schlatter J, Scholz G, Scimeca J, Slimani N, Törnqvist M, Tuijtelaars S, Verger P. 2005. Human exposure and internal dose assessments of acrylamide in food. Food Chem. Toxicol. 43: 365-410.

ECHA. 2009. Press release: 15 new substances of very high concern to be added to the Candidate List [Internet]. Helsinki (Finland): ECHA; [cited: 2009 Dec 7]. Available from: http://echa.europa.eu/doc/press/pr_09_15_msc_svhc_20091207.pdf

EFSA. 2008a. European Food Safety Authority. EFSA's 11th Scientific Colloquium - Acrylamide carcinogenicity - New evidence in relation to dietary exposure - 22 and 23 May 2008. Tabiano (Italy): EFSA; [cited 2008 May 22]. Available from: http://www.efsa.europa.eu/en/events/event/colloque080522.htm

EFSA. 2008b. Concise European Food Consumption Database. Tabiano (Italy): EFSA; [cited 
384 385 386 387 388 389 390 391 392 393 (39)

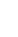

(

(3)
399 (

2A). Vol.

60

p. $\quad 389$.

Available

from: 
413 http://www.inchem.org/documents/iarc/vol60/m60-11.html

414 IRMM. 2006. Institute for Reference Materials and Measurements. Acrylamide Monitoring 415 Database (update June 2006) [Internet]. Geel (Belgium): IRMM; [cited 2006 May 31] 416 Available from: http://www.irmm.jrc.be/html/activities/acrylamide/database.htm

417 JECFA. 2005. Joint FAO/WHO Expert Committee on Food Additives. Summary and conclusions 418 of the sixty-fourth meeting of the joint FAO/WHO Expert Committee on Food Additives. 419 Rome, 8-17 February 2005. Available from: 420 http://www.who.int/ipcs/food/jecfa/summaries/summary_report_64_final.pdf

421 Kita A, Erland B, Knutsen S, Wicklund T. 2004. Effective ways of decreasing acrylamide content 422 in potato crisps during processing. J. Agric. Food Chem. 52: 7011-7016.

423 Kroes R, Muller D, Lambe J, Lowik M, van Klaveren J, Kleiner J, Massey R, Mayer S, Urieta I, 424 Verger P, Visconti A. 2002. Assessment of intake from the diet. Food Chem. Toxicol. 40: $425 \quad 327-385$.

426 Lanz I, Ternité R, Wilkens J, Hoenicke K, Guenther H, van der Stegen G. 2006. Studies on 427 acrylamide levels in roasting, storage and brewing of coffee. Mol. Nutr. Food Res. 50: 1039$428 \quad 1046$.

429 Matthys C, Bilau M, Govaert Y, Moons E, De Henauw S, Willems J. 2005. Risk assessment of 430 dietary acrylamide intake in Flemish adolescents. Food Chem. Toxicol. 43: 271-278.

431 Mestdagh F, De Wilde T, Delporte K, Van Peteghem C, De Meulenaer B. 2008a. Impact of 432 chemical pre-treatments on the acrylamide formation and sensorial quality of potato crisps. 433 Food Chem. 106: 914-922.

434 Mestdagh F, De Wilde T, Fraselle S, Govaert Y, Ooghe W, Degroodt JM, Verhe R, Van 435 Peteghem C, De Meulenaer B. 2008b. Optimization of the blanching process to reduce 436 acrylamide in fried potatoes. Food Sci. Technol. 41: 1648-1654.

437 Mestdagh F, Lachat C, Baert K, Moons E, Kolsteren P, Van Peteghem C, De Meulenaer B. 2007. 438 Importance of a canteen lunch on the dietary intake of acrylamide. Mol. Nutr. Food Res. 51: $439 \quad 509-516$.

440 Mottram D, Wedzicha B, Dodson A. 2002. Acrylamide is formed in the Maillard reaction. Nature $441 \quad 419: 448-449$. 
442 O’Brien J, Renwick A, Constable A, Dybing E, Müller D, Schlatter J, Slob W, Tueting W, van 443 Benthem J, Wiliams G, Wolfreys A. 2006. Approaches to the risk assessment of genotoxic $444 \quad$ carcinogens in food: a critical appraisal. Food Chem. Toxicol. 44: 1613-1635.

445 Seal C, de Mul A, Eisenbrand G, Haverkort A, Franke K, Lalljie S, Mykkänen H, Reimerdes E, 446 Scholz G, Somoza V, Tuijtelaars S, van Boekel M, van Klaveren J, Wilcockson S, Wilms L. 447 2008. Risk-benefit considerations of mitigation measures on acrylamide content of foods - A 448 case study on potatoes, cereals and coffee. Br. J. Nutr. 99 Suppl 2: S1-S46.

449 Stadler R, Scholz G. 2004. Acrylamide: an update on current knowledge in analysis, levels in 450 food, mechanisms of formation, and potential strategies of control. Nutr. Rev. 62: 449-467.

451 Surdyk N, Rosén J, Andersson R, Åman P. 2004. Effects of asparagine, fructose, and baking 452 conditions on acrylamide content in yeast-leavened wheat bread. J. Agric. Food Chem. 52: $453 \quad 2047-2051$.

454 Svensson K, Abramsson L, Becker W, Glynn A, Hellenäs KE, Lind Y, Rosén J. 2003. Dietary 455 intake of acrylamide in Sweden. Food Chem. Toxicol. 41: 1581-1586.

456 Taeymans D, Wood J, Ashby P, Blank I, Studer A, Stadler R, Gondé P, Van Eijck P, Lalljie S, 457 Lingnert H, Lindblom M, Matissek R, Müller D, Tallmadge D, O’Brien J, Thompson S, Silvani 458 D. 2004. A review of acrylamide: An industry perspective on research, analysis, formation, 459 and control. Crit. Rev. Food Sci. Nutr. 44: 323-347.

460 Tardiff R, Gargas M, Kirman C, Carson L, Sweeney L. 2010. Estimation of safe dietary intake 461 levels of acrylamide for humans. Food Chem Toxicol. 48: 658-667.

462 van Dooren M, Boeijen I, van Klaveren J, van Donkersgoed G. 1995. Conversion of foods to 463 primary agriculturally products. Report 95.17 [internet]. Wageningen (The Netherlands): 464 Rikilt; [cited 1995 March]. Available from: http://library.wur.nl/way/bestanden/clc/912082.pdf 465 Vose D. 2006. Risk analysis - a quantitative guide. Chichester (UK): Wiley.

466 WHO. 2006. World Health Organisation. Evaluation of certain food contaminants. Sixthy-fourth 467 report of the Joint FAO/WHO Expert Committee on Food Additives. Technical Report Series 468 930: 8-26 [internet]. Geneva (Switzerland): WHO; [cited 2006]. Available from: 469 http://whqlibdoc.who.int/trs/WHO_TRS_930_eng.pdf 
1 Figure 1. Contribution of the most important food groups to the estimated dietary exposure to

2 acrylamide in terms of \% (inner circle: P25 < P50 < P95 < outer circle: mean)

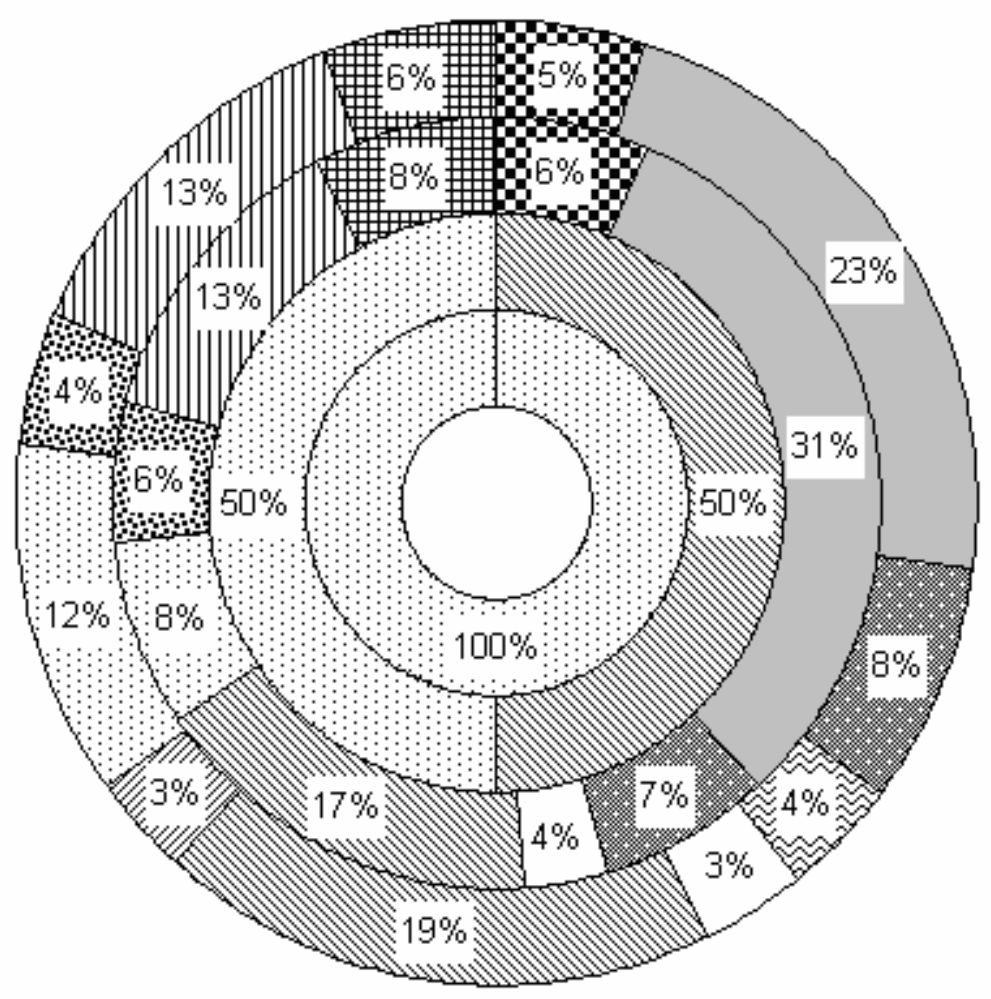

\begin{tabular}{|c|c|}
\hline $\begin{array}{l}\text { 9 breakfast cereals } \\
\text { crisps } \\
\square \text { sweet spiced biscuits } \\
\text { ख coffee surrogate } \\
\text { aread rolls }\end{array}$ & $\begin{array}{l}\square \text { chips } \\
\text { 圈 gingerbread } \\
\text { Q coffee } \\
\text { 图 bread } \\
\square \text { biscuits }\end{array}$ \\
\hline
\end{tabular}


1

1 Table 1. Contribution of the different food groups to the dietary exposure of the Belgian 2 population to acrylamide ( $\mu \mathrm{g} / \mathrm{kg}$ bw/day; best estimation [95\% confidence interval]).

\begin{tabular}{|c|c|c|c|c|c|c|c|}
\hline Food group & P25 & P50 & P75 & P90 & P95 & P97.5 & P99 \\
\hline Chips & $\begin{array}{c}0.00 \\
{[0.00-0.00]}\end{array}$ & $\begin{array}{c}0.00 \\
{[0.00-0.00]}\end{array}$ & $\begin{array}{c}0.00 \\
{[0.00-0.00]}\end{array}$ & $\begin{array}{c}0.15 \\
{[0.10-0.22]}\end{array}$ & $\begin{array}{c}0.44 \\
{[0.32-0.59]}\end{array}$ & $\begin{array}{c}0.77 \\
{[0.54-1.06]}\end{array}$ & $\begin{array}{c}1.33 \\
{[0.89-2.21]}\end{array}$ \\
\hline Crisps & $\begin{array}{c}0.00 \\
{[0.00-0.00]}\end{array}$ & $\begin{array}{c}0.00 \\
{[0.00-0.00]}\end{array}$ & $\begin{array}{c}0.00 \\
{[0.00-0.00]}\end{array}$ & $\begin{array}{c}0.00 \\
{[0.00-0.00]}\end{array}$ & $\begin{array}{c}0.10 \\
{[0.06-0.17]}\end{array}$ & $\begin{array}{c}0.32 \\
{[0.21-0.47]}\end{array}$ & $\begin{array}{c}0.67 \\
{[0.43-1.03]}\end{array}$ \\
\hline Bread & $\begin{array}{c}0.01 \\
{[0.01-0.02]}\end{array}$ & $\begin{array}{c}0.03 \\
{[0.03-0.04]}\end{array}$ & $\begin{array}{c}0.06 \\
{[0.05-0.06]}\end{array}$ & $\begin{array}{c}0.09 \\
{[0.08-0.10]}\end{array}$ & $\begin{array}{c}0.11 \\
{[0.10-0.13]}\end{array}$ & $\begin{array}{c}0.14 \\
{[0.12-0.16]}\end{array}$ & $\begin{array}{c}0.18 \\
{[0.15-0.22]}\end{array}$ \\
\hline Bread rolls & $\begin{array}{c}0.00 \\
{[0.00-0.00]}\end{array}$ & $\begin{array}{c}0.00 \\
{[0.00-0.00]}\end{array}$ & $\begin{array}{c}0.02 \\
{[0.01-0.02]}\end{array}$ & $\begin{array}{c}0.05 \\
{[0.05-0.06]}\end{array}$ & $\begin{array}{c}0.08 \\
{[0.07-0.09]}\end{array}$ & $\begin{array}{c}0.10 \\
{[0.09-0.12]}\end{array}$ & $\begin{array}{c}0.13 \\
{[0.11-0.17]}\end{array}$ \\
\hline Biscuits & $\begin{array}{c}0.00 \\
{[0.00-0.00]}\end{array}$ & $\begin{array}{c}0.00 \\
{[0.00-0.00]}\end{array}$ & $\begin{array}{c}0.00 \\
{[0.00-0.00]}\end{array}$ & $\begin{array}{c}0.07 \\
{[0.05-0.10]}\end{array}$ & $\begin{array}{c}0.18 \\
{[0.13-0.26]}\end{array}$ & $\begin{array}{c}0.34 \\
{[0.24-0.51]}\end{array}$ & $\begin{array}{c}0.64 \\
{[0.39-1.08]}\end{array}$ \\
\hline Gingerbread & $\begin{array}{c}0.00 \\
{[0.00-0.00]}\end{array}$ & $\begin{array}{c}0.00 \\
{[0.00-0.00]}\end{array}$ & $\begin{array}{c}0.00 \\
{[0.00-0.00]}\end{array}$ & $\begin{array}{c}0.00 \\
{[0.00-0.00]}\end{array}$ & $\begin{array}{c}0.00 \\
{[0.00-0.00]}\end{array}$ & $\begin{array}{c}0.15 \\
{[0.08-0.24]}\end{array}$ & $\begin{array}{c}0.36 \\
{[0.21-0.68]}\end{array}$ \\
\hline $\begin{array}{l}\text { Sweet spiced } \\
\text { biscuits }\end{array}$ & $\begin{array}{c}0.00 \\
{[0.00-0.00]}\end{array}$ & $\begin{array}{c}0.00 \\
{[0.00-0.00]}\end{array}$ & $\begin{array}{c}0.00 \\
{[0.00-0.00]}\end{array}$ & $\begin{array}{c}0.00 \\
{[0.00-0.00]}\end{array}$ & $\begin{array}{c}0.05 \\
{[0.03-0.08]}\end{array}$ & $\begin{array}{c}0.13 \\
{[0.09-0.20]}\end{array}$ & $\begin{array}{c}0.26 \\
{[0.17-0.44]}\end{array}$ \\
\hline Chocolate & $\begin{array}{c}0.00 \\
{[0.00-0.00]}\end{array}$ & $\begin{array}{c}0.00 \\
{[0.00-0.00]}\end{array}$ & $\begin{array}{c}0.00 \\
{[0.00-0.00]}\end{array}$ & $\begin{array}{c}0.05 \\
{[0.03-0.07]}\end{array}$ & $\begin{array}{c}0.11 \\
{[0.07-0.17]}\end{array}$ & $\begin{array}{c}0.18 \\
{[0.11-0.32]}\end{array}$ & $\begin{array}{c}0.32 \\
{[0.17-0.55]}\end{array}$ \\
\hline Coffee & $\begin{array}{c}0.00 \\
{[0.00-0.00]}\end{array}$ & $\begin{array}{c}0.03 \\
{[0.03-0.04]}\end{array}$ & $\begin{array}{c}0.09 \\
{[0.08-0.10]}\end{array}$ & $\begin{array}{c}0.16 \\
{[0.14-0.19]}\end{array}$ & $\begin{array}{c}0.23 \\
{[0.20-0.28]}\end{array}$ & $\begin{array}{c}0.31 \\
{[0.26-0.40]}\end{array}$ & $\begin{array}{c}0.45 \\
{[0.34-0.63]}\end{array}$ \\
\hline $\begin{array}{l}\text { Coffee } \\
\text { surrogate }\end{array}$ & $\begin{array}{c}0.00 \\
{[0.00-0.00]}\end{array}$ & $\begin{array}{c}0.00 \\
{[0.00-0.00]}\end{array}$ & $\begin{array}{c}0.00 \\
{[0.00-0.00]}\end{array}$ & $\begin{array}{c}0.00 \\
{[0.00-0.00]}\end{array}$ & $\begin{array}{c}0.00 \\
{[0.00-0.00]}\end{array}$ & $\begin{array}{c}0.00 \\
{[0.00-0.00]}\end{array}$ & $\begin{array}{c}0.34 \\
{[0.20-0.75]}\end{array}$ \\
\hline $\begin{array}{l}\text { Breakfast } \\
\text { cereals }\end{array}$ & $\begin{array}{c}0.00 \\
{[0.00-0.00]}\end{array}$ & $\begin{array}{c}0.00 \\
{[0.00-0.00]}\end{array}$ & $\begin{array}{c}0.00 \\
{[0.00-0.00]}\end{array}$ & $\begin{array}{c}0.01 \\
{[0.00-0.03]}\end{array}$ & $\begin{array}{c}0.09 \\
{[0.05-0.15]}\end{array}$ & $\begin{array}{c}0.21 \\
{[0.13-0.31]}\end{array}$ & $\begin{array}{c}0.37 \\
{[0.22-0.52]}\end{array}$ \\
\hline Toast & $\begin{array}{c}0.00 \\
{[0.00-0.00]}\end{array}$ & $\begin{array}{c}0.00 \\
{[0.00-0.00]}\end{array}$ & $\begin{array}{c}0.00 \\
{[0.00-0.00]}\end{array}$ & $\begin{array}{c}0.00 \\
{[0.00-0.00]}\end{array}$ & $\begin{array}{c}0.00 \\
{[0.00-0.01]}\end{array}$ & $\begin{array}{c}0.03 \\
{[0.01-0.05]}\end{array}$ & $\begin{array}{c}0.07 \\
{[0.03-0.13]}\end{array}$ \\
\hline Popcorn & $\begin{array}{c}0.00 \\
{[0.00-0.00]}\end{array}$ & $\begin{array}{c}0.00 \\
{[0.00-0.00]}\end{array}$ & $\begin{array}{c}0.00 \\
{[0.00-0.00]}\end{array}$ & $\begin{array}{c}0.00 \\
{[0.00-0.00]}\end{array}$ & $\begin{array}{c}0.00 \\
{[0.00-0.00]}\end{array}$ & $\begin{array}{c}0.00 \\
{[0.00-0.00]}\end{array}$ & $\begin{array}{c}0.00 \\
{[0.00-0.00]}\end{array}$ \\
\hline Cereal bars & $\begin{array}{c}0.00 \\
{[0.00-0.00]}\end{array}$ & $\begin{array}{c}0.00 \\
{[0.00-0.00]}\end{array}$ & $\begin{array}{c}0.00 \\
{[0.00-0.00]}\end{array}$ & {$\left[\begin{array}{c}0.00 \\
{[0.00-0.00]}\end{array}\right.$} & $\begin{array}{c}0.00 \\
{[0.00-0.00]}\end{array}$ & $\begin{array}{c}0.00 \\
{[0.00-0.00]}\end{array}$ & $\begin{array}{c}0.00 \\
{[0.00-0.00]}\end{array}$ \\
\hline $\begin{array}{c}\text { Intake (total) } \\
\text { ( } \mathrm{gg} / \mathrm{kg} \text { bw per } \\
\text { day) }\end{array}$ & $\begin{array}{c}0.10 \\
{[0.09-0.11]}\end{array}$ & $\begin{array}{c}0.19 \\
{[0.18-0.21]}\end{array}$ & $\begin{array}{c}0.40 \\
{[0.35-0.44]}\end{array}$ & $\begin{array}{c}0.76 \\
{[0.67-0.88]}\end{array}$ & $\begin{array}{c}1.12 \\
{[0.94-1.35]}\end{array}$ & $\begin{array}{c}1.54 \\
{[1.24-1.97]}\end{array}$ & $\begin{array}{c}2.26 \\
{[1.68-3.25]}\end{array}$ \\
\hline
\end{tabular}


4 Table 2. Comparison of 'Margins of exposure' (MOEs) determined in the present study with

5 MOE values given in literature for acrylamide

6

\begin{tabular}{|c|c|c|c|c|c|c|}
\hline \multirow{2}{*}{$\begin{array}{c}\text { T25 } \\
(\mu \mathrm{g} / \mathrm{kg} \\
\text { bw/day })\end{array}$} & \multirow{2}{*}{$\begin{array}{l}\mathrm{BMDL}_{10} \\
(\mu \mathrm{g} / \mathrm{kg} \\
\mathrm{bw} / \mathrm{day})\end{array}$} & \multirow{2}{*}{$\begin{array}{c}\text { Exposure } \\
(\mu \mathrm{g} / \mathrm{kg} \\
\text { bw/day) }\end{array}$} & \multicolumn{2}{|c|}{ MOE } & \multirow[t]{2}{*}{ Remarks } & \multirow[t]{2}{*}{ Ref. } \\
\hline & & & T25 & BMDL & & \\
\hline \multirow[t]{8}{*}{650} & 310 & 0.41 & 1600 & 760 & Mean exposure $\hat{\partial}$ (Norway) & (1) \\
\hline & & 0.42 & 1600 & 740 & Mean exposure $q$ (Norway) & (1) \\
\hline & & 0.43 & 1500 & 720 & Mean exposure (USA) & (1) \\
\hline & & 0.92 & 710 & 340 & P90 exposure (USA) & (1) \\
\hline & & 2.31 & 280 & 130 & $\begin{array}{c}\text { P90 exposure } 2-5 \text { years old } \\
\text { (USA) }\end{array}$ & (1) \\
\hline & $\begin{array}{c}200^{\mathrm{a}} \\
2000^{\mathrm{a}}\end{array}$ & $1 / 4$ & & $\begin{array}{c}200 / 50 \\
2000 / 500\end{array}$ & Mean / high exposure & (2) \\
\hline & $\begin{array}{l}2000^{\circ} \\
300\end{array}$ & $1 / 4$ & & $\begin{array}{l}2000 / 500 \\
300 / 75\end{array}$ & Mean / high exposure & (2) \\
\hline & 300 & $0.2 / 1.6$ & & $1500 / 188$ & Mean / P97.5 exposure & $\begin{array}{l}\text { Present } \\
\text { study }\end{array}$ \\
\hline
\end{tabular}

7

8 Notes: (1): O'Brien et al. 2006; (2): JECFA 2005

9 a. NOAEL ('No observed adverse effect level') instead of BMDL 10 
11 Table 3. Effect of some specific mitigation scenarios on the acrylamide intake of the Belgian

12 population (expressed as \% reduction of the intake assuming the \% decrease in AA content as

13 stated in the scenario).

14

\begin{tabular}{llcccccccc}
\hline Scenario & Average & P50 & P75 & P90 & P95 & P97.5 & P99 & P99.9 \\
\hline 1 & bread \& bread rolls -60\% & 9.7 & 29.6 & 27.6 & 15.4 & 8.0 & 5.1 & 3.3 & 1.7 \\
\hline 2 & coffee -30\% & 5.6 & 15.2 & 16.2 & 8.7 & 4.7 & 3.3 & 2.4 & 1.9 \\
\hline 3 & biscuit -70\% & 9.1 & 0.0 & 0.0 & 7.4 & 9.9 & 10.6 & 11.2 & 12.4 \\
\hline 4 & chips $-35 \%$ & 7.7 & 0.0 & 0.0 & 9.4 & 11.0 & 9.4 & 8.2 & 7.9 \\
& crisps -35\% & 2.7 & 0.0 & 0.0 & 0.0 & 2.5 & 3.6 & 4.3 & 12.4 \\
& chips \& crisps -35\% & 10.4 & 0.0 & 0.0 & 9.4 & 13.6 & 13.0 & 12.4 & 20.3 \\
\hline 5 & gingerbread -60\% & 2.2 & 0.0 & 0.0 & 0.0 & 0.0 & 3.1 & 4.2 & 4.1 \\
\hline $4+5$ & chips \& crisps -35\% + gingerbread -60\% & 12.6 & 0.0 & 0.0 & 9.4 & 13.6 & 16.1 & 16.6 & 24.5 \\
\hline
\end{tabular}

15 
16 Table 4. Application of signal values $(\mu \mathrm{g} / \mathrm{kg})$ on the acrylamide intake of the Belgian population

17 (expressed as percentage intake reduction); (1) effect of applying Belgian P90 signal values on

18 each food group separately and on all food groups together, and (2) effect of applying German

192008 signal values on all food groups together (BVL 2005).

20

\begin{tabular}{|c|c|c|c|c|c|c|c|c|c|}
\hline \multirow[t]{2}{*}{ Food group } & \multicolumn{2}{|c|}{$\begin{array}{c}\text { P90 Signal value } \\
(\mu \mathrm{g} / \mathrm{kg})\end{array}$} & \multirow[t]{2}{*}{ Average } & \multirow[t]{2}{*}{ P75 } & \multirow[t]{2}{*}{ P90 } & \multirow[t]{2}{*}{ P95 } & \multirow[t]{2}{*}{ P97.5 } & \multirow[t]{2}{*}{ P99 } & \multirow[t]{2}{*}{ P99.9 } \\
\hline & German 2008 & Belgian & & & & & & & \\
\hline Breakfast cereals & 80 & 430 & 0.2 & 0.0 & 0.0 & 0.0 & 0.0 & 0.6 & 0.4 \\
\hline Crisps & $1000(1063)^{a}$ & $1000(1053)$ & 0.8 & 0.0 & 0.0 & 0.2 & 0.2 & 0.9 & 2.3 \\
\hline Coffee & $937^{\mathrm{b}}$ & $506^{\mathrm{b}}$ & 0.0 & 0.1 & 0.1 & 0.0 & 0.0 & 0.0 & 0.0 \\
\hline Chips & $530(589)$ & 622 & 3.5 & 0.0 & 0.3 & 0.3 & 2.2 & 4.4 & 13.3 \\
\hline Biscuits & $545(738)$ & 650 & 2.7 & 0.0 & 0.1 & 0.6 & 1.5 & 2.7 & 8.1 \\
\hline Chocolate & 1 & 414 & 0.9 & 0.0 & 0.0 & 0.3 & 0.4 & 1.4 & 2.4 \\
\hline Gingerbread & $1000(1262)$ & $1000(1698)$ & 0.8 & 0.0 & 0.0 & 0.0 & 0.1 & 1.4 & 2.7 \\
\hline Sweet spiced biscuits & $416(563)$ & 719 & 0.3 & 0.0 & 0.0 & 0.1 & 0.2 & 0.4 & 0.5 \\
\hline Toast & $496(661)$ & 230 & 0.1 & 0.0 & 0.0 & 0.0 & 0.0 & 0.1 & 0.3 \\
\hline Coffee surrogate & $801(1370)^{b}$ & $\begin{array}{c}1000 \\
(3440)^{b}\end{array}$ & 1.9 & 0.0 & 0.0 & 0.0 & 0.0 & 3.9 & 5.5 \\
\hline Bread & l & 50 & 11.9 & 35.3 & 15.7 & 7.9 & 4.9 & 3.1 & 1.6 \\
\hline Bread rolls & I & 50 & 0.4 & 0.3 & 0.6 & 0.7 & 0.4 & 0.4 & 0.3 \\
\hline Popcorn & l & 494 & 0.0 & 0.0 & 0.0 & 0.0 & 0.0 & 0.0 & 0.0 \\
\hline Cereal bars & I & 135 & 0.0 & 0.0 & 0.0 & 0.0 & 0.0 & 0.0 & 0.0 \\
\hline Total: Belgian signal values ${ }^{\mathrm{C}}$ & & & 11.6 & 0.3 & 1.0 & 1.8 & 4.7 & 16.1 & 35.3 \\
\hline Total: German signal values ${ }^{c}$ & & 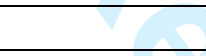 & 16.3 & 0.0 & 0.0 & 37.4 & 59.3 & 72.9 & 84.2 \\
\hline
\end{tabular}

22 Notes: ${ }^{a}$ : values between brackets are the measured but not the applied values.

$23 \quad$ b: powder

$24 \quad$ c: the effect of P90 signal values applied on all food groups considered 